\title{
Economics of Different Treatments against Brinjal Shoot and Fruit Borer, Leucinodes orbonalis (Guen.), on Brinjal, Solanum melongena (Linn.) for Higher Yield
}

\author{
Anand N. Warghat", Sanket Shekhar Mahajan, \\ Dipika S. Nimbalkar and Jagarlamudi Sagar
}

Department of Agricultural Zoology \& Entomology, Raja Balwant Singh College of
Agriculture, Bichpuri, Agra, Dr.BhimraoAmbedkar University, Agra (U.P.), India

*Corresponding author

Keywords

Economics, Brinjal, higher yield, Study, Shoot and fruit borer, Treatments,

Leucinodes orbonalis Guen.

Article Info

Accepted:

15 August 2020

Available Online:

10 September 2020

\section{A B S T R A C T}

The present investigations were carried out with a view to find out the Economics of different treatments against brinjal shoot and fruit borer, Leucinodes orbonalis (Guen.), on Brinjal, Solanum melongena (Linn.) FOR Higher Yeild at department of Agriculture Zoology and Entomology, Raja Balwant Singh College of Agriculture, Bichpuri, Agra, (U.P.). As regards to the brinjal yield, Spinosad 45 SC and Emamectin benzoate 5 SG were found most effective treatments recorded yield to $215.74 \mathrm{q} / \mathrm{ha}$ and 207.40 q/ha respectively followed by Cypermethrin $25 \mathrm{EC}$ (197.45 q/ha). As far as economics of the treatments is concerned, Cypermethrin $0.005 \%$, Metarrizium anisopliae $1 \mathrm{lit} / \mathrm{ha}$ and mechanical shoot clipping are most economic treatments recorded in ICBR of 1:39.16, 1:19.08 and 1:18.05 respectively.

\section{Introduction}

Brinjal (Solanum melongena Linnaeus) also known as eggplant is referred as the "King of vegetables" originated from India and now grown as a vegetable throughout the tropical, sub-tropical and warm temperate areas of the world. It is a most important vegetable in the Indian Subcontinent that accounts for almost $50 \%$ of the world's area under its cultivation area under its cultivation., in India, the area is estimated as $7.5 \%$ of the total area of vegetables with $8 \%$ of the total production of vegetables (Roy et al., 2016). Being high in economic value, now a day's cultivation of brinjal is becoming the menace to the farmer because of the attack of the insect pest. Among the several problem that create obstacle for brinjal productivity and quality fruits, heavy losses caused by insect pests right from seeding stage till harvest. Vevai (1970) has reported that the 26 pests which 
attacked by brinjal in India, whereas 140 species belonging to 50 families from 10 orders reported on this crop in the world. (Frengpong and buohing, 1978).For higher yield different practices are adopted and suppression of the pests on brinal are also been adopted and among these the important insect pests which invade this crop regularly are brinjal shoot and fruit borer (Leucinodes orbonalis Guen.) Brinjal stem borer (Euzophera perticella Peg.), Brijnjal hadda beetle (Epilachna deudocasting Wisel.), jassid (Amrasca bigutulla Ishida.), aphid (Aphis gossypii Glov., Myzus persicae Suiz.) whitefly (Bemisia tabaci Genn.) and red spider mites (Tetranychus telericus, Lo.), (Ratual 1986).

\section{Materials and Methods}

Materials and methods adopted in the present study entitled To Study the Economics of Different Treatments Against Brinjal Shoot And Fruit Borer Leucinodes orbonalis (Guen.), on brinjal, Solanum melongena (Linn.) for higher yield at field condition is presented below under following headings,

\section{Experimental site}

The Experiments was carried out under field conditions at the ICAR Research field, Raja Balwant Singh College, Bichpuri, Dr.Bhimrao Ambedkar University, and Agra (U.P.). Economics of seven insecticidal treatments and two bio pesticides comprising Emamectin Benzoate 5 SG, Spinosad 45 SC, Deltamethrin 2.8 EC, NSKE 5 per cent, Acephate 75 SP, Indoxacarb 14.5 SC, Profenofos 50 EC, Beauveria bassiana $1 \times$ $10^{8}$ and Metarrhiziumanisopliae $1 \times 10^{8}$ was determined during 2012-13 Brinjal variety Var. PPL was shown in Randomized Block Design. There were three replications with 2 $\times 3 \mathrm{~m}$ meter plot size. The plant spacing between row to row and plants to plant were maintained $75 \mathrm{~cm}$ and $75 \mathrm{~cm}$, respectively.

\section{Materials}

For conducting the studies, various ecofriendly chemicals and insecticides (Table 1), brinjal seed (Var. PPL), agricultural implements manure and fertilizers, bullock pair, knapsack sprayer, measuring cylinder, buckets, labels, threads, polythene bags, wax, handlenses, chemicals balance, weighing balance, labours etc. were used. These materials were provided by the department of Agricultural Zoology and Entomology, R.B.S. College Bichpuri, Agra.

\section{Methods adopted}

\section{Cultural operation}

\section{Preparatory tillage}

During summer, the soil thoroughly prepared by ploughing followed by two harrowing. The field was cleaned by picking stubbles of previous crop. Before sowing of seeds on raised beds, one harrowing was given and the experimental plots were laid out as per the statistical design.

\section{Sowing of seed on raised beds}

The seed of brinjal seed (Var. PPL), variety was sown on 17.11.2016 to raise the seedlings in nursery. Regular watering and weeding were undertaken up to transplanting seeding to the main field.

\section{Transplanting}

The seedlings were transplanted after 5-6 weeks of sowing in the main field in $5^{\text {th }}$ Dec 2016 as per layout.

\section{Gap filling}

Gap filling was done on main field to maintain the plant population, keeping behind one plant per hill. 


\section{Application of fertilizers}

Application of fertilizers was done at the rate of 60:50:50 (N.P.K.) kg/ha. Half dose of nitrogen and full dose of phosphorus and potash were given at the time of transplanting. Fertilizers were applied by ring method in the form of urea, single super phosphate (SSP) and muriate of potash (MOP).

\section{Hoeing and weeding}

Timely hoeing and weeding operation were carried out to conserve soil moisture and to remove weeds as and when needed.

\section{Irrigation}

The protective irrigation was given in field experimental plots as and when essential.

\section{Layout plan detail (Details of experiment)}

1. Year of Experiment $\quad: \quad 2016$

2. Design of Experiment : $\quad$ RBD

3. Area allotted for experiment: $14 \mathrm{~m} \mathrm{x}$ $10 \mathrm{~m}$

4. Layout plan date $\quad: \quad 03.12 .2016$

5. Plot Size $\quad: \quad 2.4 \mathrm{mx} 1.8 \mathrm{~m}$

6. Total No. of plot in each replication : 04

7. Total Replication : $\quad 04$

8. Total no. of plot : : 16

9. Variety $\quad$ : $\quad$ PPL

10. Area in bunding : $\quad 50 \mathrm{~cm}$

11. Irrigation channel (size) : $\quad 1 \mathrm{~m}$

12. Total No. of plant/per Row: 15

13. Total Row per plot : $\quad 04$

14. Total No. of plant/plot : $\quad 60$ plant/plot

15.Spacing: Row $\times$ Row $60 \mathrm{~cm}$ Plot $\times$ Plot $60 \mathrm{~cm}$
16. Date of Planting :

05.12 .2016

17. Total Number of treatment $: 09$

\section{Calculation of avoidable losses}

The avoidable loss due to pests was worked out using the following formulae given by (Pradhan, 1983).

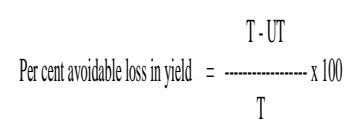

Where,

$\mathrm{T}=$ Yield in treated plot.

UT $=$ Yield in untreated plot.
First Spray

Second Spray

Third Spray
December 14, 2016

February 24, 2016

April 3, 2017

\section{Yield of brinjal fruits}

In order to compare the effectiveness of different treatments on the basis of fruit yield.

The picking of marketable brinjal fruit was done periodically and yield obtained in the net plot at each treatment was recorded. The plot wise yield thus obtained was further converted into hectare basis.

\section{Statistical methods}

The data obtained in number of percentage in different treatments were transformed into corresponding square root or arc sine value as per Gomez and Gomez (1984) and were subjected to statistical analysis of variance. 
Table.1 Eco-friendly chemicals and insecticides

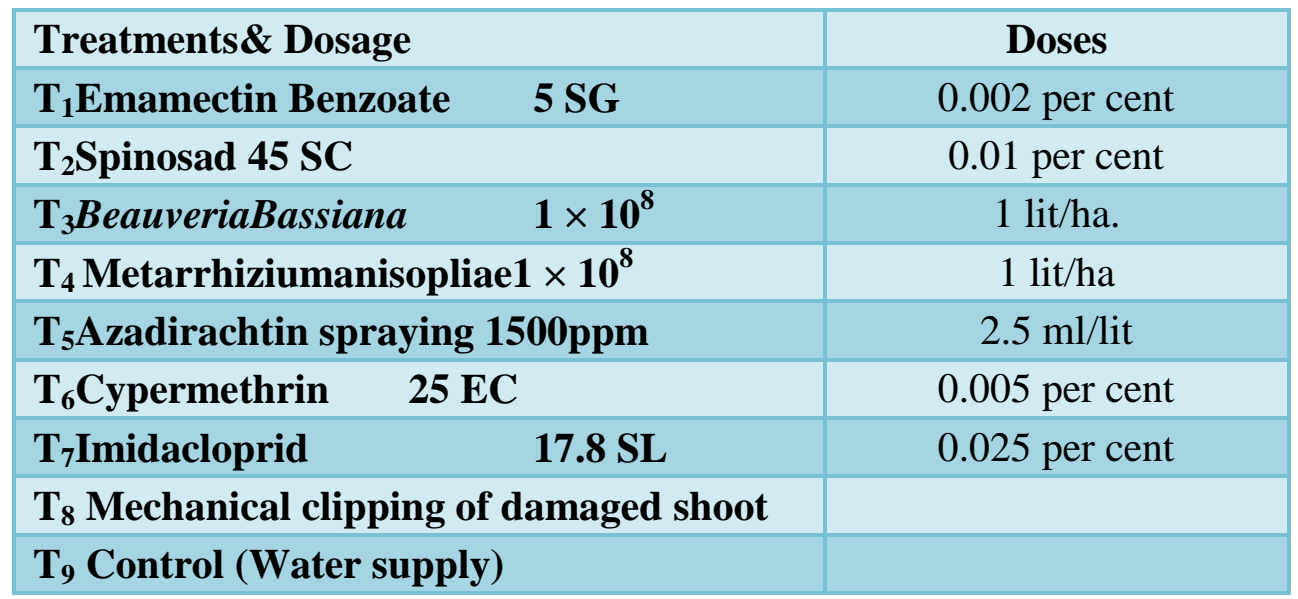

Table.2 Effect of various treatments on yield

\begin{tabular}{|c|c|c|c|}
\hline Tr. No. & Treatment & $\begin{array}{c}\text { Yield per plot } \\
(\mathbf{K g})\end{array}$ & $\begin{array}{c}\text { Increased yield per plot } \\
\text { over control (Kg) }\end{array}$ \\
\hline $\mathbf{T}_{\mathbf{1}}$ & Emamectin benzoate 5 SG @ 0.002\% & 8.96 & 4.23 \\
& & $(207.40)$ & $(97.91)$ \\
\hline $\mathbf{T}_{\mathbf{2}}$ & Spinosad 45 SC @ 0.01\% & 9.32 & 4.49 \\
& & $(215.74)$ & $(106.25)$ \\
\hline $\mathbf{T}_{\mathbf{3}}$ & Beauveriabassiana 1 x 10 @ 1 lit/ha & 7.27 & 2.54 \\
\hline & & $(168.28)$ & $(58.79)$ \\
\hline $\mathbf{T}_{\mathbf{4}}$ & Metarrihiziumanisopliae 1 x 10 $@$ @ 1 lit/ha & 7.75 & 3.02 \\
& & $(179.39)$ & $(69.90)$ \\
\hline $\mathbf{T}_{\mathbf{5}}$ & Azadirachtin 1500 ppm @ 2.5 ml/lit & 6.98 & 2.25 \\
\hline & & $(161.57)$ & $(52.08)$ \\
\hline $\mathbf{T}_{\mathbf{6}}$ & Cypermethrin 25 EC @ 0.005\% & 8.53 & 3.8 \\
\hline $\mathbf{T}_{\mathbf{7}}$ & & $(197.45)$ & $(87.96)$ \\
\hline & & 8.03 & 3.3 \\
\hline $\mathbf{T}_{\mathbf{8}}$ & Imidacloprid 17.8 SL @ 0.025\% & $(185.87)$ & $(76.88)$ \\
\hline $\mathbf{T}_{\mathbf{9}}$ & & 6.37 & 1.64 \\
\hline & Mechanical Shoot clipping & $(147.22)$ & $(37.73)$ \\
\hline & Control (Water spray) & 4.73 & \\
\hline & & $(109.49)$ & \\
\hline & F-test & Sig. & \\
\hline
\end{tabular}

(Figures in parentheses are arc sin transformed values)* 
Table.3 Incremental cost benefit ratio in different treatments

\begin{tabular}{|c|c|c|c|c|c|c|c|c|c|c|c|}
\hline $\begin{array}{l}\text { Tr. } \\
\text { No. }\end{array}$ & Treatment & $\begin{array}{c}\text { Qty. of } \\
\text { Insecticides } \\
\text { req./ha for } 3 \\
\text { spray }\end{array}$ & $\begin{array}{r}\text { Cos } \\
\text { treat } \\
(\mathbf{R s} .\end{array}$ & $\begin{array}{l}\text { of } \\
\text { lent } \\
\text { la) }\end{array}$ & $\begin{array}{l}\text { Total } \\
\text { Cost } \\
\text { (A) }\end{array}$ & $\begin{array}{l}\text { Yield } \\
\text { q/ha }\end{array}$ & $\begin{array}{l}\text { Increase } \\
\text { yield over } \\
\text { control } \\
\text { (q/ha) }\end{array}$ & $\begin{array}{l}\text { Value of } \\
\text { increased } \\
\text { yield } \\
\text { (Rs./ha) }\end{array}$ & $\begin{array}{l}\text { Increment } \\
\text { benefit }(\mathrm{C}) \\
(\mathrm{B}-\mathrm{A})\end{array}$ & $\begin{array}{r}\text { ICBR } \\
\text { (C/A) }\end{array}$ & Rank \\
\hline 1 & $\begin{array}{c}\text { Emamectin benzoate } 5 \\
\text { SG @ } 0.002 \%\end{array}$ & $600 \mathrm{gm}$ & 4200 & 990 & 5190 & 207.40 & 97.91 & 48955 & 43785 & 18.73 & VII \\
\hline 2 & $\begin{array}{c}\text { Spinosad 45 SC @ } \\
0.01 \%\end{array}$ & $333 \mathrm{ml}$ & 4884 & 990 & 5874 & 215.74 & 106.25 & 53125 & 47251 & $1: 10.25$ & VI \\
\hline 3 & $\begin{array}{c}\text { Beauveriabassiana } 1 x \\
10^{8} @ 1 \text { lit/ha }\end{array}$ & 3 lit & 750 & 990 & 1740 & 168.28 & 58.79 & 29395 & 27655 & $1: 15.89$ & IV \\
\hline 4 & $\begin{array}{c}\text { Metarrihizium } \\
\text { anisopliae } 1 \times 10^{8} @ 1 \\
\text { lit/ha }\end{array}$ & 3 lit & 750 & 990 & 1740 & 179.39 & 69.90 & 34950 & 33210 & $1: 19.08$ & I \\
\hline 5 & $\begin{array}{l}\text { Azadirachtin } 1500 \\
\text { ppm @ } 2.5 \text { ml/lit }\end{array}$ & $3750 \mathrm{ml}$ & 1125 & 990 & 2250 & 161.57 & 52.08 & 26040 & 23790 & $1: 10.57$ & $\mathrm{~V}$ \\
\hline 6 & $\begin{array}{c}\text { Cypermethrin } 25 \mathrm{EC} \\
@ 0.005 \%\end{array}$ & $300 \mathrm{ml}$ & 105 & 990 & 1095 & 197.45 & 87.96 & 43960 & 42885 & $1: 19.15$ & I \\
\hline 7 & $\begin{array}{c}\text { Imidacloprid } 17.8 \mathrm{SL} \\
\text { @ } 0.025 \%\end{array}$ & $1685 \mathrm{ml}$ & 3201 & 990 & 4191 & 185.87 & 76.88 & 36440 & 34249 & $1: 8.17$ & VIII \\
\hline 8 & $\begin{array}{l}\text { Mechanical Shoot } \\
\text { clipping }\end{array}$ & - & - & 990 & 990 & 147.22 & 37.73 & 18865 & 17875 & 1:18.05 & III \\
\hline 9 & Control (Water spray) & & - & & & 109.49 & - & & & & \\
\hline
\end{tabular}

Note-
a) Labour charges - Rs. 150/day

b) Spray Pump charge - Rs. 30/day

Emamectin benzoate $5 \mathrm{SG}-700$ Rs./day
d)Spinosad $45 \mathrm{SC}-1100 \mathrm{Rs} / 75 \mathrm{ml}$ g)Azadirachtin 1500ppm - 300Rs./lit

e)Beauveriabassiana - $250 \mathrm{Rs} . / 1$ lith)Cypermethrin $25 \mathrm{EC}-350 \mathrm{Rs} / \mathrm{lit}$ f)Metarrhizium anisopliae - $250 \mathrm{Rs} . / 1$ lit i) Imidacloprid $17.8 \mathrm{SL}-190 \mathrm{Rs} . / 100 \mathrm{ml}$ 
Fig.1 Effect of various treatments on yield

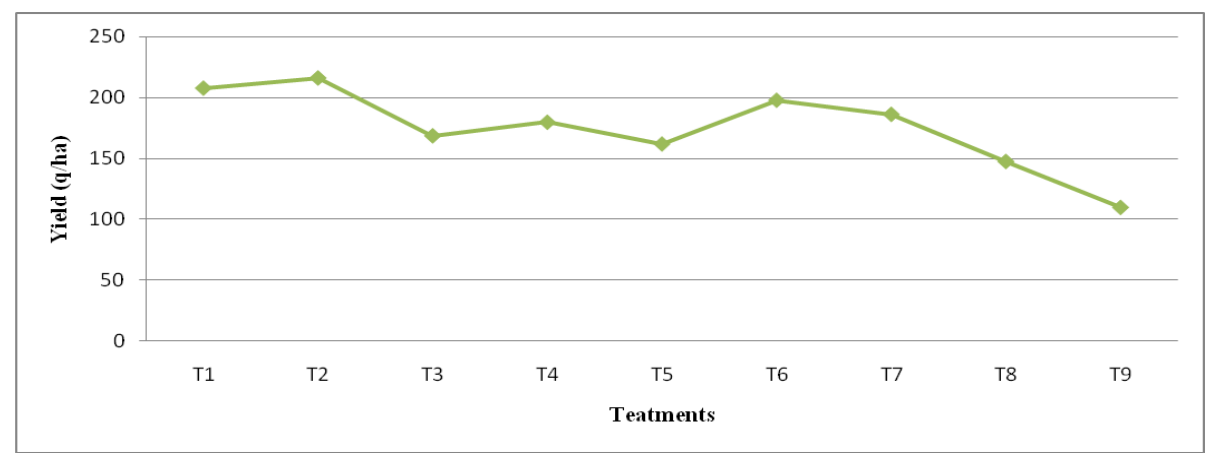

Fig.2 Incremental cost benefit ratio in different treatments

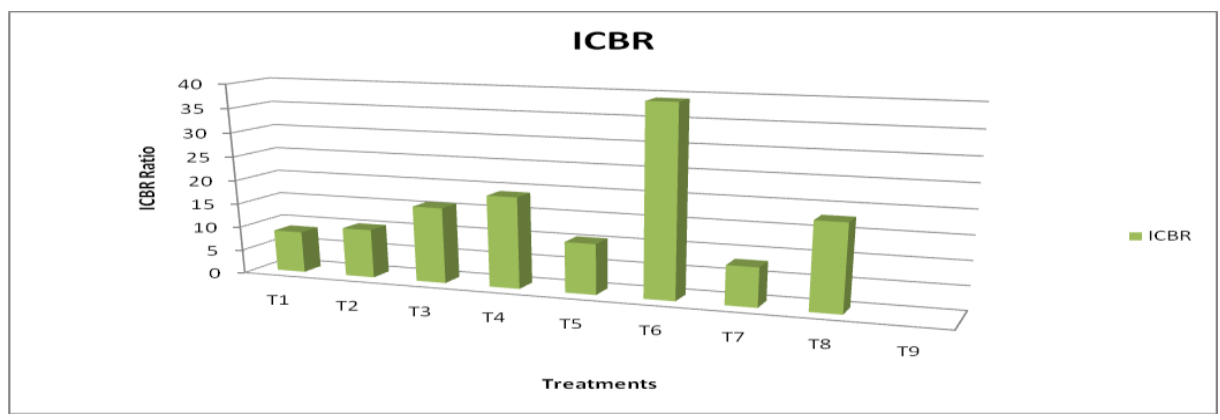

\section{Results and Discussion}

The data, thus obtained, were subjected to statistical analysis after doing the corresponding transformation for further interpretation of results. Based on yield of brinjal fruit and costs of input incurred for each treatment, the ICBR was also worked out. The results thus obtained are summarized below.

The highest yield of brinjal fruit was obtained from the treatment spinosad $0.01 \%$ being superior to next effective treatments Emamectin benzoate $0.002 \%$, cypermethrin $0.005 \%$, Imidacloprid $0.025 \%$.On the basis of ICBR among the effective treatments, cypermethrin was appeared to be the most economically viable treatment followed by Metarrhizium anisopliae 1 lit/ha, mechanical shoot clipping, Beauveria bassiana 1 lit/ha, Azadirachtin $2.5 \mathrm{ml} / \mathrm{lit}$. Thus, it can be concluded that, spinosad $0.01 \%$ was proved to be the best treatment in managing the brinjal shoot and fruit borer producing higher marketable fruit yield followed by next best treatment was Emamectin benzoate $0.002 \%$, However the application of botanicals and mechanicals shoot clipping was relatively lesser utility in managing the brinjal shoot and fruit borer.

Investigation on were study of Economics of Different Treatments Against Brinjal Shoot And Fruit Borer, Leucinodes orbonalis (Guen.), on brinjal, Solanum melongena (Linn.) for higher yield undertaken during Rabi season of 2016-2017 on the ICAR research field of R.B.S. Agriculture College Bichpuri, Agra. The consisted of nine treatments replicated thrice in Randomized Block Design. The treatment wise yield obtained at each picking was added together for computing total yield obtained at each treatment.

\section{Yield}

The data in respects of yield as influenced by 
various treatments on brinjal fruit revealed that the treatment with spinosad $0.01 \%$ which recorded the highest yield of brinjal fruits $(215.14 \mathrm{q} / \mathrm{ha})$ appearing most promising treatment in getting brinjal fruit yield. The overall effectiveness of treatments on the basis of yield in ascending order were emamectin benzoate $0.002 \% \quad(207.40 \mathrm{q} / \mathrm{ha})$ >cypermethrin $\quad 0.005 \% \quad(197.45 \mathrm{q} / \mathrm{ha})$ >imidacloprid $\quad 0.025 \% \quad(185.87 \mathrm{q} / \mathrm{ha})$ $>$ Metarrhizium anisopliae $1 \mathrm{li} / \mathrm{ha}$ $(179.39 \mathrm{q} / \mathrm{ha})>B$. bassiana $1 \mathrm{lit} / \mathrm{ha}$ $(168.28 \mathrm{q} / \mathrm{ha}) \quad>$ Azadirachtin $2.5 \mathrm{ml} / \mathrm{lit}$ (161.28q/ha), > mechanical shoot clipping was found $(147.22 \mathrm{q} / \mathrm{ha})$, whereas control (water spray), (109.49q/ha) (Fig. 1 and 2; Table 1-3).

\section{ICBR (Incremental Cost Benefit Ratio)}

The data in respect of incremental cost benefit ratio as influenced by various treatments revealed that, the incremental cost benefit ratio was obtained in the treatment of Cypermethrin $0.005 \%$ (1:39.16) followed by Metarrhizium anisopliae $1 \mathrm{~kg} / \mathrm{ha}$ (1:19.08), > mechanical shoot clipping (1:18.05) >Beauveria bassiana $1 \mathrm{~kg} / \mathrm{ha}$ (1:15.89), $>$ Azadirachtin $2.5 \mathrm{ml} / \mathrm{lit}$ (1:10.57), >spinosad $0.01 \% \quad(1: 10.25), \quad>$ Emamectin benzoate $0.002 \%$ (1:8.43), >Imidacloprid 17.8 SL @ $0.025 \%(1: 18.17)$.

\section{References}

Anonymous, 2006. Annual Report, ICAR Pub, New Delhi, pp.95.

Anonymous,2008. Area and production of brinjal in Maharashtra. http.www.nhb.gov.in

Aycord, W.R. 1983. The nutritive value of Indian food and planning of satisfactory diets, ICMR Special Report No. 42.

Gomez, K.H. and A.A. Gomez, 1984. Statistical procedure for agricultural Research, Textbooks.

Chakraborti, S. (2001). A bio rational approach for a management of brinjal shoot and fruit borer (Leucinodes orbonalis G.). Journal of Entomological Research 25 (1): 73-76.

Deshmukh, R. M. and Bhamare, V. K. (2006) Field evaluation of some insecticides against brinjal shoot and fruit borer, Leucinodes orbonalis Guenee, International Journal of Agricultural Sciences, 2 (1): 247-249.

Mathur, A., Singh, S., Singh, N. P. and Meena, M., (2012) "Field evaluation of plant products and microbial formulations against brinjal shoot and fruit borer, Leucinodes orbonalis Guenee under semi-arid conditions of Rajasthan." Journal of Biological pesticide, 5 (1): 71-74.

Singh, P. and VishwaNath. (2007) "Field evaluation of insecticide and neem formulations for a management of brinjal shoot and fruit borer, Leucinodes orbonalis. G in brinjal." Indian Journal Entomological Research, 69(4): 341-344.

Vevai, E. J. (1970). Know your crop its pest problems and control brinjal pest. Pesticides. 4(4): 26-35.

\section{How to cite this article:}

Anand N. Warghat, Sanket Shekhar Mahajan, Dipika S. Nimbalkar and Jagarlamudi Sagar. 2020. Economics of Different Treatments against Brinjal Shoot and Fruit Borer, Leucinodes orbonalis (Guen.), on Brinjal, Solanum melongena (Linn.) for Higher Yield. Int.J.Curr.Microbiol.App.Sci. 9(09): 1786-1792. doi: https://doi.org/10.20546/ijcmas.2020.909.223 